\title{
Prospects for agricultural lands afforestation in Poland until 2020
}

\author{
Adam Kaliszewski 凶, Wojciech Młynarski, Piotr Gołos
}

Forest Research Institute, Department of Forest Resources Management, Sękocin Stary, Braci Leśnej 3, 05-090 Raszyn, Poland, phone: +48 22 7150678, e-mail: a.kaliszewski@ibles.waw.pl

\section{Abstract}

The aim of the paper is to present the potential for afforestation of agricultural lands under the 'National Programme for Expanding of Forest Cover' (KPZL) in Poland until 2020. The analysis is based on the ongoing social and economic changes in rural areas in the past decade as well as factors limiting implementation of the Programme. The data used have been derived from annual reports of the Agricultural Property Agency (ANR), the Central Statistical Office and also other official documents and legal acts related to the issue.

Assuming that the area of agricultural lands transferred by the ANR to the State Forests Holding - an institution responsible for implementing the KPZL on state-owned lands - remains approximately 350 ha per year, the overall extent of afforestation on state-owned lands will not exceed 4,500-4,600 ha until 2020. In case of private lands, a further decline in annual afforestation area will be observed. The lack of a stable financing system is a major reason for the decrease in the area of agricultural lands transferred for afforestation. The projections show that the average annual afforestation area on private lands will not exceed 2,500 ha until 2020. Altogether, it can be expected that during the period 2015-2020, approximately 20,000 ha of agricultural lands will be afforested.

The study shows that the current rate of afforestation is insufficient for reaching the target defined in the KPZL (afforestation of 680,000 ha of lands during the period 2001-2020). Low supply of private lands for afforestation and insufficient financial support for farmers are the most important factors limiting the implementation of the KPZL. The situation could be improved by free transfer of public lands for afforestation from the ANR to the State Forests Holding and by implementing financial instruments for afforestation of private lands from the Forest Fund resources.

\section{KeY WORDS}

agricultural policy, forest cover expansion, forest policy, rural development

\section{INTRODUCTION}

Expansion of forest cover is one of the main aims of the Polish forest policy. According to the 'National Policy on Forests', adopted by the Council of Ministers in 1997 , the forest cover should reach $30 \%$ of the total area of the country by 2020 and $33 \%$ by 2050 (National Policy on Forests 1997). According to the Central Statistical Office, forests currently cover $29.4 \%$ of the land area of Poland (Forestry 2014).

Afforestation in Poland is performed under the 'National Programme for Expanding of Forest Cover' 
(KPZL). The Programme was adopted by the Council of Ministers in 1995 (National Programme 1995), but it never became a so-called 'government programme', because no financial means for its implementation in long term had been guaranteed. The aim of KPZL is to ensure that conditions are favourable for expansion of forest cover to up to $30 \%$ of the country's land area, secure optimal distribution of afforestation, set up ecological and economic priorities as well as programme implementation instruments. The Programme has been implemented since 1995 and will be completed in 2020 . From 1995 to 2000, a preparatory phase of the Programme was implemented (National Programme 1995).

According to KPZL, from 2001 to 2020, the expected afforested area would be spread over 680,000 ha, which would include 130,000 ha of lands owned by the State Treasury (state-owned lands) and 550,000 ha of private lands. In detail, it was assumed that, for individual periods, area of new forests cover on agricultural lands would be as follows:

- 2001-2005 - 24,000 ha annually, including 14,000 ha of private lands,

- 2006-2010 - 32,000 ha annually, including 24,000 ha of private lands,

- 2011-2020 - 40, 000 ha annually, including 36,000 ha of private lands (National Programme 2003).

Between 2001 and 2014, approximately 163,000 ha of agricultural lands were afforested throughout the country, 101,600 ha of which accounted for private lands and 61,400 ha for lands owned by the State Treasury. The rate of implementation of the Programme for this period amounted to $37 \%$.

The rate of implementation of KPZL was particularly unfavourable during the past decade (2005-2014): only $32 \%$ of lands owned by the State Treasury and $21 \%$ of private lands were afforested (the overall implementation rate amounted to $23 \%$ ). Since 2010 , the annual rate of implementation of KPZL has decreased from $18 \%$ to $9 \%$ (Kaliszewski et al. 2014).

The most important obstacles in the way of implementation of the 'National Programme for Expanding of Forest Cover', which actually caused its collapse, arose mostly from socioeconomic changes in the rural areas following Poland's accession to the European Union (EU) in May 2004. Research results indicate that the most important factors limiting the performance of KPZL during the past decade involve:
- high competitiveness of transferring agricultural lands for non-agricultural and non-forest purposes,

- high competitiveness of direct payments for agricultural production compared to afforestation premium,

- lack of financial support for afforestation of lands within Natura 2000 areas, which are yet to be covered by protection plans,

- exclusion of permanent grasslands from afforestation,

- enlarging minimal plot areas supported by afforestation premium from 0.1 to 0.3 ha in 2004 and up to 0.5 ha in 2007 ,

- weak promotion of financial support for afforestation among farmers and their training courses,

- complicated procedures for granting financial support.

Most of the aforementioned factors appear to be permanent and long term (Kaliszewski 2012; Kaliszewski et al. 2014).

The Rural Development Programme (RDP) of 2014-2020, which is the most important instrument for supporting afforestation of private lands, introduces several significant changes in comparison to the previous RDP of 2007-2013 (RDP 2007) in terms of rules and procedures for granting financial aid for afforestation. They include, inter alia, verified afforestation payments, annual premium per hectare to cover the costs of agricultural income foregone and maintenance, covering agricultural lands afforested with EU financial support in previous years with area payments (from 2015 onward) and decreasing to 0.1 ha - in certain cases - a minimal afforested area eligible for granting financial aid (RDP 2014). The Programme, however, does not remove any other significant barriers that arose after 2004. For the analysis of prospects for afforestation of agricultural lands until 2020, it was assumed that in case of lands owned by the State Treasury (state-owned lands), the implementation of KPZL would be mostly limited by a deficit of lands suitable for establishing new forests, while in the private sector, afforestation would be mostly limited and hampered by a shortage and insufficiency of financial means, discouraging farmers from planting new forests on agricultural lands and permanently excluding them from agricultural production (Kaliszewski 2012; Łazowy 2015).

The aim of this paper is to present the potential for afforestation of agricultural lands under the KPZL in 
Poland until 2020. The analysis is based on ongoing social and economic changes in rural areas in the past decade as well as factors limiting the implementation of the Programme, presented by Kaliszewski et al. (2014).

\section{Methods}

The potential supply of state-owned lands suitable for afforestation in the period of 2015-2020 was estimated based on the information about availability of land for afforestation in the resources of the Agricultural Property Agency (ANR) and the State Forests National Forest Holding. The data were derived from annual reports of the ANR and from the Central Statistical Office (GUS).

The projection for afforestation area of private lands until 2020 was made based on the observed 10year trend of the area afforested annually and also taking into account the rules for financing afforestation provided in the RDP 2014-2020 (RDP 2014), as well as the results of the survey on the factors limiting afforestation in non-state lands (Kaliszewski et al. 2014).

Legal regulations and their amendments have been characterised based on the legislation listed in the Legal Acts Database (ISAP), managed by the administration services of the Sejm (the lower chamber of the Polish Parliament) (Online Legislation System 2016).

\section{Results}

\section{Afforestation of lands owned by the State Treasury}

State-owned lands for afforestation are transferred to the State Forests (which performs establishment of new forests in the field) by the ANR. The ANR is a government institution authorised by the State Treasury to perform process of restructuring and privatisation of agricultural property of the State Treasury. The property taken over by the ANR constitutes the Agricultural Property Stock of the State Treasury.

The transfer of land is made according to the provisions of the Forest Act (Act of 28 September 1991) and the Act on Management of Agricultural Property of the State Treasury (Act of 19 October 1991). The current wording of the Article 24 par. 4 of the latter act states that, at the request of the ANR, a local district authority shall transfer free of charge separate plots intended for afforestation in an area development plan or a zoning permit to the State Forests Holding. Until 2010, the ANR could also transfer to the State Forests free of charge forested areas as well as lands suitable for afforestation, other than those specified in Article 24 par. 4 quoted previously. It was possible to make such a transfer by means of a contractual agreement between the Head of the ANR and the General Director of the State Forests (par. 4a). In 2010, this regulation was overruled by the Parliament (Act of 26 November 2010). Furthermore, in 2011, the Agency was obliged, first of all, to sell the state-owned property instead of transferring it free of charge, even in case of lands intended for afforestation (Act of 16 September 2011). Thus, by this means, all possibilities of free distribution of state-owned lands belonging to the Agricultural Property Stock of the State Treasury was ultimately strictly limited.

From 1992 to 2014, the ANR transferred free of charge to the State Forests altogether 153,700 ha of lands for afforestation. They included mainly lands of VI and VIz classes (i.e. very weak arable lands), lands located in watershed and groundwater reservoir areas, and enclaves surrounded by forests managed by the State Forests and adjacent to these forests (Report 2015).

Between 2004 and 2014, the ANR transferred to the State Forests more than 21,400 ha of lands for afforestation. During this period, new forests were established on more than 21,200 ha of land (Fig. 1). Until 2011, an average area transferred by the Agency amounted to 2800 ha annually. However, from 2011 onwards, it has substantially decreased to about 380 ha per year, reaching its minimal value in 2012 (232 ha). The decline resulted from the previously mentioned legislative changes. Nevertheless, at the end of 2014, the ANR was in possession of 29,800 ha of land formally destined for afforestation (Report 2015).

According to the Local Data Bank of the GUS, at the end of 2014, the area of non-forest lands designated for afforestation by the State Forests amounted to 3200 ha (Local Data Bank 2015). Assuming that until $202080 \%$ of those land would be afforested (because of the delay between the lands transfer and their actual afforestation) and the area of lands transferred by the ANR would amount to approximately 350 ha annually, in the period 2015-2020, approximately 4500-4600 ha of state-owned lands may be afforested (Fig. 2). 


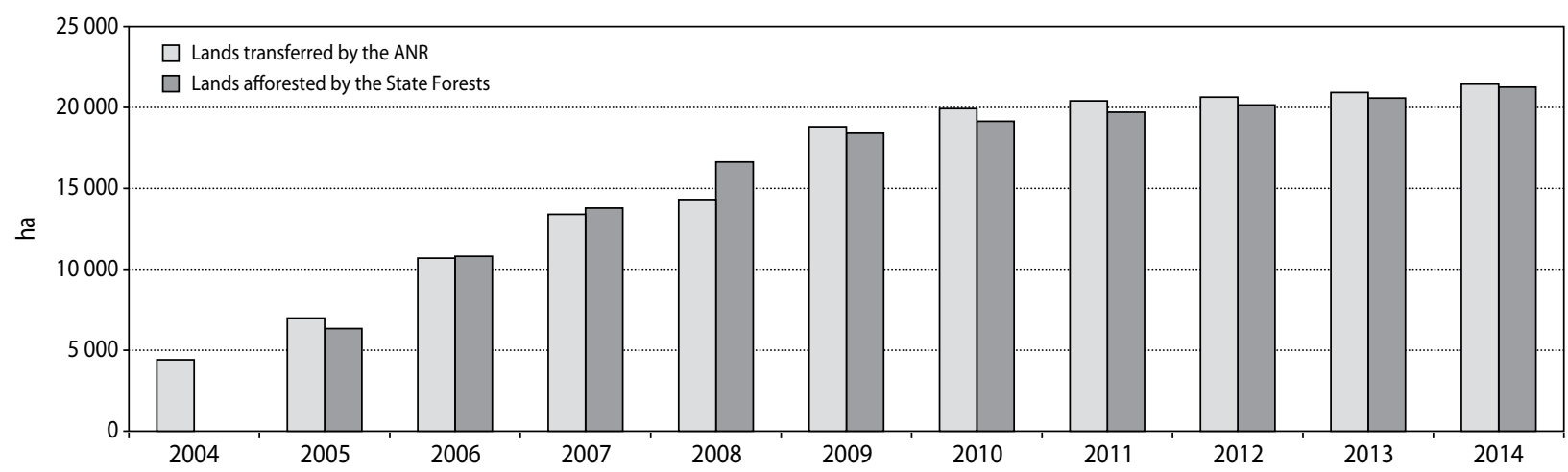

Figure 1. Cumulated area of lands for afforestation transferred to the State Forests by the Agricultural Property Agency (ANR) and cumulated afforested area during 2005-2013. For 2004, only the area of transferred lands has been presented

Source: Own elaboration based on data from the ANR and the Central Statistical Office.

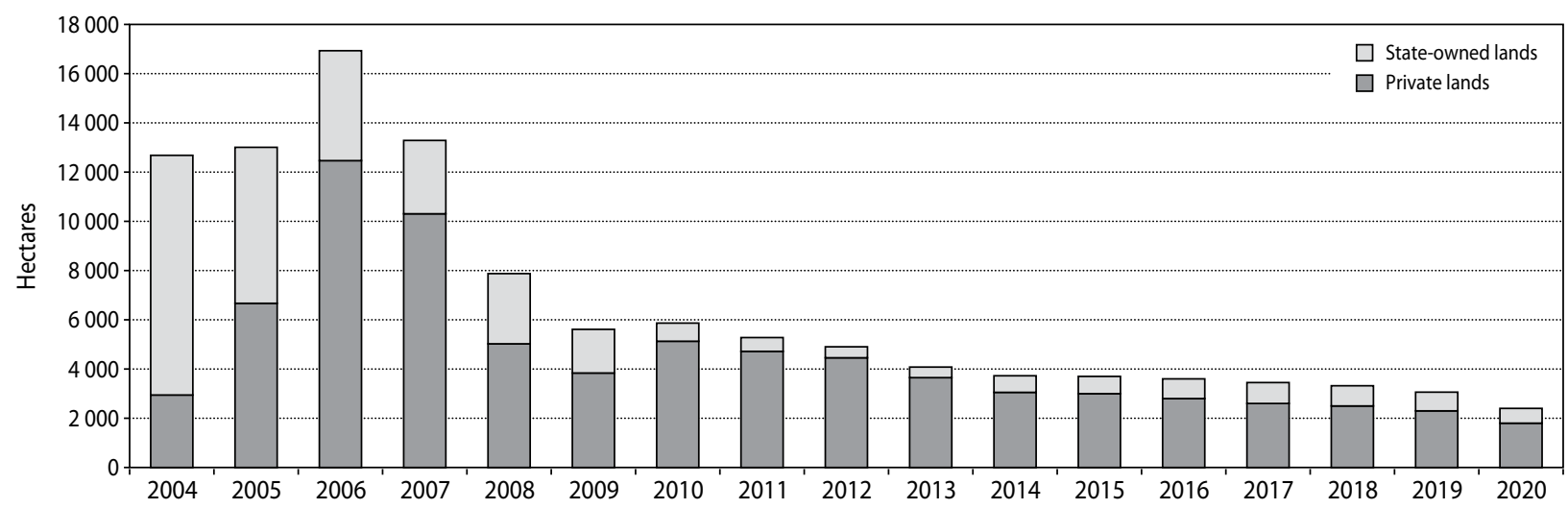

Figure 2. Area of afforestation during 2004-2014 and predictions for afforestation of agricultural lands during 2015-2020

Source: Own elaboration based on data from the Central Statistical Office.

As regards regional distribution of lands for afforestation possessed by the ANR, most areas of lands are managed by its branch offices in Szczecin (11,300 ha), Wrocław (10,000 ha), Olsztyn (3600 ha) and Gdańsk (1300 ha) (Report 2015). Thus, it is very likely that afforestation will be carried out mainly in the following provinces: Zachodnio-Pomorskie (north-western Poland), Dolnośląskie (south-west), Wamińsko-Mazurskie (north-east) and Pomorskie (northern Poland). Afforestation in the Małopolskie, Podkarpackie and Świętokrzyskie Provinces (southern and central Poland) can only be performed on the lands already (up to 2015) transferred to the State Forests, as the ANR does not possess anymore lands formally destined for afforestation in those regions.

\section{Afforestation of private lands}

Between the years 2014 and 2020, afforestation of private (non-state) agricultural lands will be predominantly carried out under the RDP 2014-2020, which is the most important support instrument for development of agriculture and rural areas. Its 'Afforestation and creation of woodland' is the only activity under the 'Investments in forest area development and improvement of the viability of forests' in the Polish RDP 2014-2020 (RDP 2014).

The total aid (i.e. along with national co-financing) provided under the 'Afforestation and creation of woodland' in the RDP 2014-2020 amounts to EUR 301 million for the entire duration of the programme. The total financial follow-up commitments for the 'Afforestation of agricultural land and afforestation of non-agricultural land' of the RDP 2007-2013 and the 'Afforestation of 
agricultural land' of the RDP 2004-2006 have been estimated at about EUR 270 million. These commitments will be financed under the 'Afforestation and creation of woodland' of the RDP 2014-2020 and the amount covers new applications submitted by farmers in 2014 (RDP 2014).

The average total amount of aid granted for afforestation (i.e. new applications) in the period 2009-2013 amounted to PLN 43.5 million per year (Reports 2010-2014). For new afforestation to be implemented in the period 2015-2020, about EUR 31 million have been allotted (RDP 2014). Based on the average exchange rate as of September 2015 (EUR $1=$ PLN 4.19; National Bank 2015), it makes some PLN 129.9 million, which is below PLN 22 million annually.

Payments for afforestation under RDP 2007-2013 (altogether 27,400 ha) made by the Agency for Restructuring and Modernization of Agriculture, the accredited paying agency, amounted to PLN 538.8 million. Only in 2014, they totalled PLN 90.6 million (Report 2014). Given these values, the sum of approximately PLN 129.9 million allocated for this purpose for the period 2015-2020 seems to be dramatically insufficient not only to increase the annual extension of afforestation but even to maintain it at the current level.

Between 2007 and 2013, the area of private lands afforested annually decreased from 10,300 to 3,600 ha. In 2014 , less than 3,100 ha were afforested. With no stable system of financing of afforestation, further decline in the annual area of afforestation may become a fact. Based on the above assumptions, it can be presumed that from 2015 to 2020, the extent of new afforestation on the private lands will not exceed 15,000 ha, that is, on average, 2,500 ha annually (Fig. 2).

It is difficult to determine the regional distribution of the oncoming afforestation, because they are not limited by potential agricultural land availability. Based on the analysis of current trends in regional distribution of afforestation, it is most likely that new private forests may be located in Warmińsko-Mazurskie, Mazowieckie and Lubelskie Provinces, that is, in north-eastern, central and eastern regions of Poland. The areas with least afforestation will probably be in Opolskie, Śląskie and Małopolskie Provinces, that is, in the southern part of the country (Kaliszewski et al. 2014).

The rate of implementation of KPZL on private lands (according to the objectives set out in the Pro- gramme's revision of 2003) is likely to reach about $22 \%$. The Programme will be most successful in the following provinces: Warmińsko-Mazurskie (87\%), KujawskoPomorskie (59\%) and Lubuskie (40\%), while the least success rate will be attained in Śląskie (8\%), Wielkopolskie (9\%), Małopolskie (11\%), Świętokrzyskie (13\%) and Łódzkie (14\%).

\section{Discussion}

The estimates presented for the period of 2015-2020 show that altogether afforestation of approximately 20,000 ha of agricultural lands, mostly private ones (75\%), may be expected. Thus, throughout the period of the implementation of 'National Programme for Expanding of Forest Cover' (2001-2020), approximately 183,000 ha would be afforested, which means $27 \%$ of the originally planned extent. The main factors affecting the breakdown of the KPZL implementation are long-term and it does not seem possible to displace them in the coming years.

According to Łazowy, from farmers' point of view, under neither the RDP 2007-2013 nor the RDP 2014-2020, were the full cost of changing agricultural lands to forests financially compensated. After agricultural lands are afforested, the landowners permanently lose the possibility of converting their afforested lands back to agricultural lands. The current support system under the RDP does not take it into account. The landowners are granted only costs of afforestation, tending young stands and a possible income loss from agricultural production as a result of establishment of a new forest (for a period of 12 years). Thus, it seems reasonable that landowners are also compensated for the permanent loss of their lands and thus not being able to engage in more profitable agricultural production. This would also require granting them a land value equivalent (Lazowy 2015). The average price of poor arable land (land of $\mathrm{V}$ and VI classes) in 2013 amounted to PLN 20,200 per 1 ha (Statistical Yearbook 2014) and based on such a sum, the aid for farmers should be increased (Lazowy 2015).

The limited financial resources allocated for the activity of 'Afforestation and creation of woodland' under the RDP 2014-2020 urge to search for other sources of the KPZL financing. To some extent, afforestation programme could be supported with domestic financial re- 
sources, namely, those allocated to the Forest Fund, which is the internal compensatory fund of the State Forests Holding. The legal basis for domestic support is delivered by the Commission Regulation (EU) No 702/2014, declaring certain categories of aid in the agricultural and forestry sectors and in rural areas compatible with the internal market in application of Articles 107 and 108 of the Treaty on the Functioning of the European Union (Regulation 702/2014). According to the Art. 32 of the Regulation, additional national aid may be granted for afforestation or the creation of woodland on agricultural and non-agricultural land and may include, inter alia, costs of the plantation material, plantation costs and costs directly linked to the plantation, costs of necessary prevention and protection material as well as costs of replanting necessary during the first year of afforestation. However, because of the Forest Fund legal structure, such aid would have to exclude direct profits for landowners and thus include only lands other than agricultural ones, that is, only those forested (partially) through natural succession or lands protected because of their watershed and soil protective functions, where as a rule no afforestation premium for forest owners is granted.

Commission Regulation (EU) No 702/2014 specifies that, in order to ensure compliance with the Regulation of the European Parliament and of the Council (EU) No 1305/2013 of 17 December 2013 for support of rural development by the European Agricultural Fund for Rural Development (EAFRD) and to simplify the rules for approving state aid for co-financed part by the EAFRD and additional funding of RDPs, the aid should be granted only under the RDP and in accordance with that programme (par. (62) and Art. 32 par. 2) (Regulation 702/2014). As the responsibility of the paying agency in the Polish RDP 2014-2020 is borne by the Agency for Restructuring and Modernization of Agriculture, it would be reasonable if it would support administratively the aid from the Forest Fund.

The increase in the extent of afforestation rate in state-owned lands would be feasible after the possibility to transfer lands allocated for afforestation from the ANR to the State Forests is restored. At the end of 2014, there were approximately 30,000 ha of such lands (Report 2015). The main obstacle is caused by the obligation for the ANR to sell the property it manages in the first place, which considerably limits free land distribution to other public agencies and institutions.

\section{Conclusions}

The results of the study and data analysis allow to draw the following conclusions:

- According to the observed dynamics of afforestation, it may be assumed that it will not be possible to reach a goal formulated in the KPZL to afforest 680,000 ha of agricultural lands in the period of 2001-2020.

- Currently, the most important limiting factors are shortage of lands suitable for afforestation (stateowned property) as well as insufficient financial resources available for afforestation and related compensations (private lands).

- It is recommended to restore the opportunity to transfer lands designated for afforestation free of charge from the ANR to the State Forests.

- In view of the limited resources allocated to the measure of 'Afforestation and creation of woodland' under the RDP 2014-2020, it seems reasonable to consider the possibility of launching domestic aid for this purpose from the Forest Fund.

\section{ACKNOWLedgements}

The paper presents the results of the research implemented within the project 'Revision of the "National Programme for Expanding of Forest Cover" 2014' financed by the National Fund for Environmental Protection and Water Management to the order of the Minister of the Environment (grant number DLP/16/2014). The authors would like to thank the personnel of the Department of Forest Management at the Directorate-General of the State Forests in Warsaw and to Mr. Stanisław Łazowy from the Regional Directorate of the State Forests in Gdańsk for their precious help throughout the project.

\section{References}

Act of 16 September 2011 amending the Act on the Management of Agricultural Real Estate of the State Treasury and some other acts (in Polish). 2011. Off. J. No. 233 item 1382.

Act of 19 October 1991 on Management of Agricultural Real Estate of the State Treasury and amending 
some other acts (in Polish). 1991. Off. J. No. 107 item 464.

Act of 26 November 2010 on amending some budgetrelated acts (in Polish). 2010. Off. J. No. 238 item 1578 with amendments.

Act of 28 September 1991 on Forests (in Polish). 1991. Codified version. Off. J. 2015 item 2100.

Commission Regulation (EU) No 702/2014 of 25 June 2014 declaring certain categories of aid in the agricultural and forestry sectors and in rural areas compatible with the internal market in application of Articles 107 and 108 of the Treaty on the Functioning of the European Union. 2014. Off. J. EU L 193/1, 1.7.2014.

Forestry 2015. 2015. Central Statistical Office, Warsaw.

Kaliszewski A. 2012. Problems implementing the "National Programme for Expanding of Forest Cover" following Poland's accession to the European Union (in Polish with English summary). Leśne Prace Badawcze, 73 (3), 189-200.

Kaliszewski A., Wysocka-Fijorek E., Jabłoński M., Młynarski W. 2014. Revision of the „National Programme for Expanding of Forest Cover” 2014 (in Polish). Forest Research Institute, Sękocin Stary.

Łazowy S. 2015. End of afforestation? Problems implementing the „National Programme for Expanding of Forest Cover". In: Proceedings of the fifth Expert Panel of the National Forest Programme (eds.: A. Kaliszewski, K. Rykowski), 17 September 2014 (in Polish). Forest Research Institute, Sękocin Stary, 145-161.
Local Data Bank. 2015. Central Statistical Office, Warsaw. https://bdl.stat.gov.pl/BDL/start. Accessed 25 November 2015.

National Bank of Poland (in Polish). 2015. NBP Newsletter, 8, 35 .

National Policy on Forests. 1997. Document accepted by the Council of Ministers on 22 April 1997 (in Polish). Ministry of Environmental Protection, Natural Resources and Forestry, Warsaw.

National Programme for Expanding of Forest Cover (in Polish). 1995. Ministry of Environmental Protection, Natural Resources and Forestry, Warsaw.

National Programme for Expanding of Forest Cover. Revision 2003 (in Polish). 2003. Ministry of the Environment, Warsaw.

Online Legislation System (in Polish). 2016. Chancellery of the Sejm of the Republic of Poland, Warsaw. http://isap.sejm.gov.pl/. Accessed 20 February 2016.

Report of Activities of the Agricultural Property Agency in 2014 (in Polish). 2015. Agricultural Property Agency, Warsaw.

Reports of Activities of the Agency for Restructuring and Modernisation of Agriculture for 2009-2013 (in Polish). 2010-2014. Agency for Restructuring and Modernisation of Agriculture, Warsaw.

Rural Development Programme for 2007-2013 (in Polish). 2007. Ministry of Agriculture and Rural Development, Warsaw.

Rural Development Programme for 2014-2020. Updated 12 December 2014 (in Polish). 2014. Ministry of Agriculture and Rural Development, Warsaw.

Statistical Yearbook of Agriculture 2014 (in Polish). 2014. Central Statistical Office, Warsaw. 